\title{
Mast Cell Tryptase Is a Mitogen for Cultured Fibroblasts
}

\author{
Stephen J. Ruoss," Thomas Hartmann, ${ }^{*}$ and George H. Caughey** \\ ${ }^{*}$ Cardiovascular Research Institute and ${ }^{\ddagger}$ Department of Medicine, University of California, San Francisco, CA 94143
}

\begin{abstract}
Mast cells appear to promote fibroblast proliferation, presumably through secretion of growth factors, although the molecular mechanisms underlying this mitogenic potential have not been explained fully by known mast cell-derived mediators. We report here that tryptase, a trypsin-like serine proteinase of mast cell secretory granules, is a potent mitogen for fibroblasts in vitro. Nanomolar concentrations of dog tryptase strongly stimulate thymidine incorporation in Chinese hamster lung and Rat-1 fibroblasts and increase cell density in both subconfluent and confluent cultures of these cell lines. Tryptase-induced cell proliferation appears proteinase-specific, as this response is not mimicked by pancreatic trypsin or mast cell chymase. In addition, low levels of tryptase markedly potentiate DNA synthesis stimulated by epidermal growth factor, basic fibroblast growth factor, or insulin. Inhibitors of catalytic activity decrease the mitogenic capacity of tryptase, suggesting, though not proving, the participation of the catalytic site in cell activation by tryptase. Differences in $\mathrm{Ca}^{++}$mobilization and sensitivity to pertussis toxin suggest that tryptase and thrombin activate distinct signal transduction pathways in fibroblasts. These data implicate mast cell tryptase as a potent, previously unrecognized fibroblast growth factor, and may provide a molecular link between mast cell activation and fibrosis. (J. Clin. Invest. 1991. 88:493-499.) Key words: proteinase - proliferation • growth factor $\bullet$ signal transduction $\cdot$ chymase
\end{abstract}

\section{Introduction}

Several lines of evidence suggest participation of mast cells in fibroblast proliferation. Increased numbers of mast cells are found in close proximity to proliferating fibroblasts in healing wounds and in fibrotic diseases of the lung and skin in humans (1-4). These observations have received support from animal models of lung fibrosis induced by ionizing radiation, bleomycin, or asbestos, which lead to mast cell hyperplasia early in the development of fibrosis (5-7). In the hypersensitivity pneumonitis model of lung fibrosis in mast cell-deficient $\mathrm{W} / \mathrm{W}^{\mathrm{v}}$ mice, mast cells are required to produce the full pathologic response (8), suggesting a central role for mast cells in the fibroblast proliferation. Furthermore, morphologic studies of the lung parenchyma in interstitial fibrosis (1), fibrotic airway subepithelium in chronic asthma (9), and lesional skin in

Address correspondence and reprint requests to Dr. George $\mathbf{H}$. Caughey, Cardiovascular Research Institute, University of California, San Francisco, CA 94143-0911.

Received for publication 22 June 90 and in revised form 25 March 91

J. Clin. Invest.

(C) The American Society for Clinical Investigation, Inc.

0021-9738/91/08/0493/07 \$2.00

Volume 88, August 1991, 493-499 scleroderma (10) provide evidence of mast cell degranulation, suggesting that granule constituents may participate in the proliferative process. This hypothesis has been examined in vitro in rodent experiments, which demonstrate cell proliferation after mast cell degranulation (11). Activation of mast cells results in extracellular release of histamine, the serine proteinases tryptase and chymase, and other mediators (12-15). Although histamine has some growth-promoting potential (16), its activity accounts only partially for the mitogenic potential of mast cell granule contents $(17,18)$, implying the existence of additional mast cell-derived growth factors.

Extensive work has established mitogenic activity for thrombin and other proteinases in various cell types including fibroblasts (19-21). We have explored the possible role for mast cell proteinases in fibroblast proliferation by examining the mitogenic activity of purified dog tryptase and chymase in cultured fibroblasts.

\section{Methods}

Materials. Benzoyl-val-gly-arg-p-nitroanilide (VGR-pNA), ${ }^{1}$ D-Phe-Lpipecolyl-Arg-p-NA, succinyl-phe-pro-phe-p-nitroanilide (FPF-pNA), amiloride, bovine heparin, leupeptin, diisopropylfluorophosphate (DFP), epidermal growth factor (EGF), bovine insulin, and human $\alpha$-thrombin $(3,700 \mathrm{NIH} \mathrm{U} / \mathrm{ml})$ were obtained from Sigma Chemical Co. (St. Louis, MO). Basic fibroblast growth factor (bFGF) was kindly provided by Dr. D. Gospodarowicz (University of California, San Francisco). Pertussis toxin was from List Biological Laboratories (Campbell, CA). Fura-2-acetoxymethylester (AM) was obtained from Molecular Probes, Inc. (Eugene, OR). (Methyl- ${ }^{3} \mathrm{H}$ )-thymidine deoxyribose and $\left[{ }^{14} \mathrm{C}\right]$ benzoic acid were from ICN Biomedicals (Irvine, CA), and myo$\left(2-{ }^{3} \mathrm{H}\right.$ )-inositol was obtained from Amersham Corp. (Arlington Heights, IL). Mast cell tryptase (22) and chymase (23) were purified from dog mastocytoma cells.

Cell culture. Chinese hamster lung (CHL) fibroblasts (clone CCL39), an established diploid cell line, were obtained from the American Type Culture Collection (Rockville, MD). Rat-1 fibroblasts were obtained from the laboratory of Dr. H. Bourne (University of California, San Francisco). All cells were grown in DMEM containing 4.5 $\mathrm{g} /$ liter glucose, and supplemented with $10 \% \mathrm{FCS}, 50 \mathrm{U} / \mathrm{ml}$ penicillin, $50 \mu \mathrm{g} / \mathrm{ml}$ streptomycin, and $25 \mathrm{mM} \mathrm{Na}^{+}$bicarbonate, at $37^{\circ} \mathrm{C}$ in $5 \% \mathrm{CO}_{2}$.

Mast cell proteinase catalytic assays. Dog mast cell tryptase and chymase were assayed using the specific chromogenic peptide substrates VGR-pNA and FPF-pNA, respectively, as previously described $(22,23)$. Briefly, purified enzyme solutions were incubated with the respective $p$-nitroanilide substrates at $37^{\circ} \mathrm{C}$, with measurement of absorbance at $394 \mathrm{~nm}$ performed using an 8451 A Diode Array Spectrophotometer (Hewlett-Packard, Palo Alto, CA). Established specific activities for these proteinases were used to determine molar concentrations $(22,23)$, using the tetrameric molecular weight $(140,000 \mathrm{D})$ for tryptase and monomeric molecular weight for chymase.

1. Abbreviations used in this paper: bFGF, basic fibroblast growth factor; CHL, Chinese hamster lung; DFP, diisoprophylfluorophosphate; EGF, epidermal growth factor; fura-2-AM, fura-2-acetoxymethylester; FPF-pNA, succinyl-phe-pro-phe-p-nitroanilide; VGR-pNA, benzoylval-gly-arg-pNA. 
Measurement of DNA synthesis. CHL cells were grown to confluence in 24-well plates and rendered quiescent by $24 \mathrm{~h}$ incubation in serum-free DMEM. After serum deprivation, cells were incubated for $24 \mathrm{~h}$ with agonists in DMEM/Ham's F-12 medium (1:1) in the presence of $\left[{ }^{3} \mathrm{H}\right]$ thymidine $(0.5 \mu \mathrm{Ci} / \mathrm{ml})$. Growth factors were added simultaneously in experiments where multiple mediators were applied. Purified tryptase or chymase, when added, were applied to cells in $270 \mathrm{mM}$ $\mathrm{NaCl}, 10 \mathrm{mM}$ Bis-Tris (pH 6.1) buffer. When present, bovine heparin was added in a 2.5:1 weight excess over tryptase. Controls included buffer and heparin alone. After the 24-h incubation period with [ ${ }^{3} \mathrm{H}$ ]thymidine, trichloroacetic acid-precipitable material was solubilized in $0.3 \mathrm{~N} \mathrm{NaOH}$, and the incorporated radioactivity was assessed by liquid scintillation counting. Thymidine incorporation assays for Rat- 1 cells followed the same protocol as above, with the exception that $\left[{ }^{3} \mathrm{H}\right]$ thymidine $(0.5 \mu \mathrm{Ci} / \mathrm{ml})$ was added to the culture medium for the final 6 $\mathrm{h}$ of the total $21 \mathrm{~h}$ of incubation with mitogens.

Pertussis toxin sensitivity assays. Assay of pertussis toxin-induced inhibition of DNA synthesis was performed as previously described (24). Briefly, pertussis toxin was added to quiescent CHL fibroblasts, at the concentrations indicated in Results, $4 \mathrm{~h}$ before stimulation and was present throughout the 24 -h incubation with growth factors. [ $\left.{ }^{3} \mathrm{H}\right]$ Thymidine incorporation was assessed as described above.

Cell proliferation assays. Stimulation of cells at low density and at high density was used to establish the characteristics of cell proliferation in response to tryptase. In the low density experiments, $\mathrm{CHL}$ cells were plated at 2,500 cells $/ \mathrm{cm}^{2}$ in multi-well plates containing DMEM with $10 \%$ FCS. After $24 \mathrm{~h}$, cells were washed three times with serumfree DMEM and covered with DMEM/Ham's F-12 medium (1:1), supplemented with transferrin $(5 \mu \mathrm{g} / \mathrm{ml})$ and insulin $(10 \mu \mathrm{g} / \mathrm{ml})$. Growth factors, as listed in Results, were added to cells in serum-free medium at the time of medium change, and every second day subsequently with accompanying medium change. On days of medium change, cells were suspended with trypsin and counted using a hemocytometer; duplicate wells were counted for each condition.

In the high density experiments, CHL cells were grown to confluence in $10 \%$ FCS then deprived of serum for $24 \mathrm{~h}$ in DMEM. Quiescent cells were then stimulated with tryptase $(2 \mathrm{nM})$, thrombin (10 $\mathrm{nM}$ ), or $10 \%$ FCS. After a $36-\mathrm{h}$ incubation with growth factors, cell density was determined by counting as above.

Studies with tryptase inhibitors. To examine the role of tryptase catalytic activity in the observed mitogenic responses, the effects of active site inhibition by leupeptin and DFP were examined.

(a) Leupeptin studies. The reversible, arginal-class inhibitor leupeptin was added to quiescent $\mathrm{CHL}$ cells concomitant with tryptase or other growth factors, as indicated below; the final leupeptin and growth factor concentrations were as given in Results. Inhibition of mitogenic activity was assessed by $\left[{ }^{3} \mathrm{H}\right]$ thymidine incorporation.

(b) DFP studies. Tryptase $(3 \mu \mathrm{M})$ and thrombin $(1 \mu \mathrm{M})$ were incubated independently with DFP for $21 \mathrm{~h}$ at $4^{\circ} \mathrm{C}$ before exposure to cells. Molar ratios of DFP to enzyme ranged from $3 \times 10^{1}$ to $10^{4}$ for tryptase, and from $10^{-2}$ to $10^{4}$ for thrombin. The 21 -h preincubations were necessary to allow hydrolysis of excess unincorporated DFP, which is cytotoxic. All incubations were performed in $270 \mathrm{mM} \mathrm{NaCl}, 10 \mathrm{mM}$ Hepes (pH 6.1) buffer. Control DFP solutions, in concentrations corresponding to those used in the proteinase coincubations, also were incubated at $4^{\circ} \mathrm{C}$ for $21 \mathrm{~h}$. Complete DFP hydrolysis after $21 \mathrm{~h}$ of incubation was confirmed by the inability of the incubation solutions to inhibit the amidolytic activity of fresh tryptase or thrombin. Amidolytic activity was assessed with chromogenic substrates as described below. Aliquots of proteinases in the absence of DFP were incubated under identical conditions to assure preservation of proteinase activity during these incubations. Aliquots of the proteinase preparations above were added to quiescent $\mathrm{CHL}$ cells to final concentrations of $7.5 \mathrm{nM}$ (tryptase) or $10 \mathrm{nM}$ (thrombin). [ $\left.{ }^{3} \mathrm{H}\right]$ Thymidine incorporation was measured as described above. Catalytic activity of tryptase and thrombin was measured immediately after the $21 \mathrm{~h}$ incubation at $4^{\circ} \mathrm{C}$. Tryptase was assayed using VGR-pNA (22), and thrombin catalytic activity was assessed using the method of Witting et al. (25), with D-Phe-L-pipecolylArg- $p$-NA $(200 \mu \mathrm{M})$.
Determination of intracellular $\mathrm{pH}$ change. Intracellular $\mathrm{pH}$ change was determined from the equilibrium distribution of $\left[{ }^{14} \mathrm{C}\right]$ benzoic acid as described (26). Briefly, quiescent $\mathrm{CHL}$ fibroblasts in 12-well plates were equilibrated for $1 \mathrm{~h}$ in bicarbonate-free Hepes-buffered DMEM (pH 7.4), at $37^{\circ} \mathrm{C} .\left[{ }^{14} \mathrm{C}\right]$ Benzoic acid $(1 \mu \mathrm{Ci} / \mathrm{ml})$ was present for the final $30 \mathrm{~min}$ of equilibration. Cells were then stimulated for $10 \mathrm{~min}$ with tryptase or thrombin at concentrations of 7.5 and $1 \mathrm{nM}$, respectively. When present, amiloride $(1 \mathrm{mM})$ was added $5 \mathrm{~min}$ before addition of growth factors. Stimulation of cells was stopped by aspiration of external medium and rapid washing four times with ice-cold unlabeled medium. Retained $\left[{ }^{14} \mathrm{C}\right]$ benzoic acid was measured by liquid scintillation counting. Changes in intracellular $\mathrm{pH}$ were calculated as previously described (27).

Measurement of intracellular calcium. Free cytosolic $\mathrm{Ca}^{++}$was measured in CHL cells using the fluorescent indicator fura-2. CHL cells grown to confluence on glass coverslips were loaded with fura-2AM (1 $\mu \mathrm{M}$ ) in Hank's buffer with $20 \mathrm{mM}$ Hepes (pH 7.4), for $15 \mathrm{~min}$ at $37^{\circ} \mathrm{C}$. Cells were then washed twice with dye-free buffer and mounted in a cuvette with continuous stirring. Tryptase $(7.5 \mathrm{nM})$ and thrombin ( $1 \mathrm{nM})$ were added to the cuvette while recording. Fluorescence was recorded in a fluorimeter (SLM 8000; SLM Instruments, Inc., Urbana, IL), changing excitation wavelengths every second between 340 and $380 \mathrm{~nm}$. Emitted light above $495 \mathrm{~nm}$ was recorded. Background was determined after permeabilizing the cells with mellitin $(10 \mu \mathrm{g} / \mathrm{ml})$ and addition of $1 \mathrm{mM} \mathrm{MnCl}$. The ratio of light intensities upon excitation at 340 and $380 \mathrm{~nm}$ was used to calculate free cytosolic $\mathrm{Ca}^{++}$concentration, assuming a $K_{d}$ of $224 \mathrm{nM}$ for the $\mathrm{Ca}^{++}$-fura-2 complex (28).

Measurement of inositol phosphates. Formation of inositol phosphates was assayed as previously described (29). Confluent CHL fibroblasts in 12-well plates were incubated for $24 \mathrm{~h}$ in serum-free DMEM containing $\left[{ }^{3} \mathrm{H}\right]$ inositol $(2 \mu \mathrm{Ci} / \mathrm{ml})$. After equilibration in Hepes-buffered DMEM (pH 7.4) for $30 \mathrm{~min}, 10 \mathrm{mM} \mathrm{LiCl}$ was added to increase assay sensitivity through inhibition of inositol-1-phosphatase (30). LiCl-treated cells were exposed to tryptase $(7.5 \mathrm{nM})$ or thrombin (1 $\mathrm{nM}$ ) for $10 \mathrm{~min}$. Cells were then extracted with $10 \mathrm{mM}$ formic acid, and total radiolabeled inositol phosphates were assessed by anion-exchange chromatography and liquid scintillation counting (29).

\section{Results}

Tryptase induced the incorporation of $\left[{ }^{3} \mathrm{H}\right]$ thymidine in confluent quiescent $\mathrm{CHL}$ cells up to 22 -fold above control levels. This corresponded to $65 \%$ of the response to $10 \%$ FCS (Fig. 1 a). Tryptase also initiated DNA synthesis in confluent serumdeprived Rat-1 fibroblasts. The thymidine incorporation response to tryptase observed in Rat-1 was greater than that observed in CHL cells, with the response of Rat-1 cells to $15 \mathrm{nM}$ tryptase equaling the response to $10 \%$ FCS (Fig. $1 b$ ). The halfmaximal response tryptase concentration was $\sim 4 \mathrm{nM}$ for both cell lines. In contrast to tryptase, the thymidine uptake observed in Rat-1 cells in response to thrombin, trypsin, or chymase (a chymotrypsin-like mast cell serine proteinase) was minimal (Fig. 1 b). Higher concentrations of trypsin or chymase resulted in cell rounding and detachment from the plates, whereas lower concentrations of these proteinases produced thymidine uptake that only approached control levels (Fig. 1 b). Thus, tryptase-induced DNA synthesis appeared to be a specific response. Similar effects for chymase and trypsin were observed in quiescent CHL cells (data not shown). These results suggest that proteolysis per se is not sufficient to induce DNA synthesis in the fibroblast cell lines investigated.

To confirm that cell growth accompanies DNA synthesis after tryptase stimulation, cell numbers were determined after CHL cell exposure to tryptase under two different cell density conditions. First, CHL cells were seeded in 10\% FCS at low density, then shifted to serum-free medium after $24 \mathrm{~h}$. Cells 

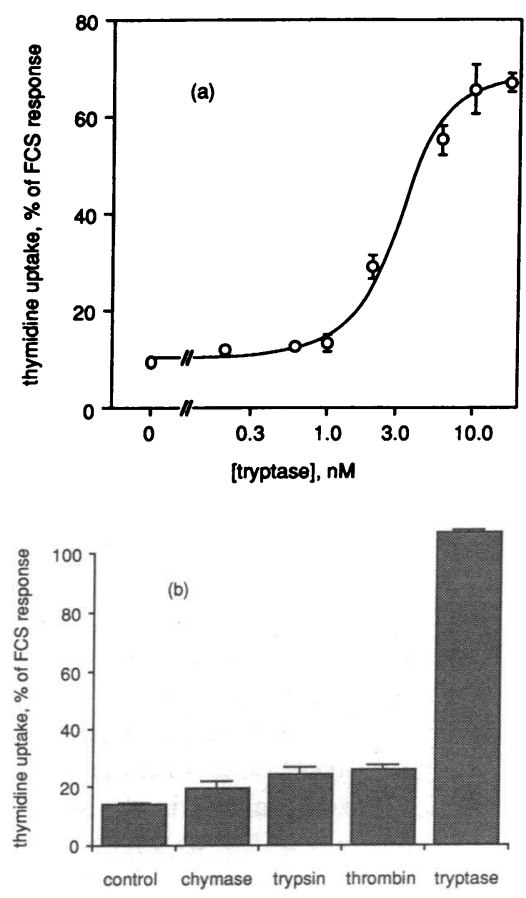

Figure 1. Concentration-dependent reinitiation of DNA synthesis in fibroblasts by dog tryptase. (a) Quiescent, confluent CHL fibroblasts were incubated for $24 \mathrm{~h}$ with purified dog tryptase, from 0.25 to $22.5 \mathrm{nM}$, in the presence of $\left[{ }^{3} \mathrm{H}\right]$ thymidine. (b) Serum-deprived confluent Rat-1 fibroblasts were incubated for $18 \mathrm{~h}$ with chymase (3 nM), trypsin (100 $\mathrm{nM})$, tryptase (15 nM), and thrombin (10 nM). Results of incorporation of $\left[{ }^{3} \mathrm{H}\right]$ thymidine are normalized to the response to $10 \%$ FCS. Mean \pm SE of 5 to 20 independent determinations are shown.

maintained in the presence of insulin and transferrin alone did not proliferate (Fig. 2). In contrast, cell number increased 8fold after $6 \mathrm{~d}$ in the presence of $2 \mathrm{nM}$ tryptase, with a subsequent plateau in cell density (Fig. 2). In the presence of $1 \mathrm{nM}$ thrombin, CHL cell number increased 20 -fold in the same period (Fig. 2). CHL cells did not reach confluence under these conditions, but confluence was achieved by $6 \mathrm{~d}$ with incubation in $10 \% \mathrm{FCS}$ or $10 \mathrm{nM}$ thrombin. Higher concentrations of tryptase did not increase growth rate or final cell density. The mechanism for a cessation of tryptase-induced cell growth at subconfluence remains unknown.

To examine induction of cell proliferation by tryptase at high cell density, confluent serum-deprived $\mathrm{CHL}$ cells were stimulated with $7.5 \mathrm{nM}$ tryptase, $10 \mathrm{nM}$ thrombin or $10 \%$ FCS. Cell counts assessed $36 \mathrm{~h}$ after stimulation demonstrated that tryptase was equivalent to thrombin or $10 \%$ FCS in promoting growth (Table I). In each condition cell number increased over controls by $\sim 60 \%$. Similar results were obtained for confluent, serum-deprived Rat-1 cells, where cell number increased by 39.7 and $42.4 \%$ after tryptase and FCS exposure,

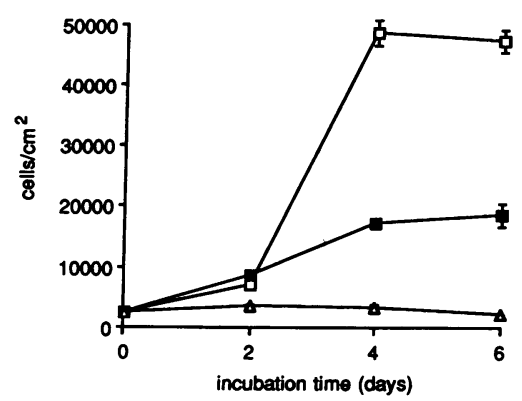

Figure 2. Effect of tryptase on cell proliferation in low density CHL fibroblasts. CHL cells were seeded at 2,500 cells $/ \mathrm{cm}^{2}$ in medium containing $10 \%$ FCS. After $24 \mathrm{~h}$, cells were washed and covered with serum-free medium supplemented with transferrin and insulin. Fresh medium supplemented with transferrin and insulin was added to cells alone (open triangles), or with $2 \mathrm{nM}$ tryptase (closed squares) or $1 \mathrm{nM}$ thrombin (open squares), every second day. Cells were counted in a Neubauer chamber, triplicate wells were counted for each condition. Data represent mean \pm SD.

Table I. Cell Proliferation in Confluent Fibroblasts after Mitogen Exposure

\begin{tabular}{lll}
\hline \multirow{2}{*}{ Stimulus } & \multicolumn{2}{c}{ Cells $\left(\times 10^{5} / \mathrm{cm}^{2}\right)^{*}$} \\
\cline { 2 - 3 } Control & \multicolumn{1}{c}{$\mathrm{CHL}$} & \multicolumn{1}{c}{ Rat-1 } \\
\hline 7.5 nM Tryptase & $2.43 \pm 0.15$ & $4.03 \pm 0.38$ \\
$10 \mathrm{nM}$ Thrombin & $3.80 \pm 0.31^{\ddagger}$ & $5.63 \pm 0.18^{\ddagger}$ \\
$10 \%$ FCS & $3.90 \pm 0.45^{\ddagger}$ & $3.81 \pm 0.25$ \\
& $3.98 \pm 0.40^{\ddagger}$ & $5.74 \pm 0.29^{\ddagger}$ \\
\hline
\end{tabular}

Cell counts $36 \mathrm{~h}$ after exposure to mitogens.

* Mean \pm SEM for triplicate determinations. ${ }^{*}$ A significant difference from control $(P<0.05)$ by Student $t$ test.

respectively (Table I). Thrombin did not significantly increase Rat- 1 cell number over baseline, in agreement with the failure of thrombin to stimulate thymidine incorporation in these cells (Fig. $1 b$ ). These results indicate that tryptase not only stimulates S-phase entry in fibroblasts, but also promotes completion of the cell cycle, resulting in cell division.

To examine the interaction between tryptase and other growth factors, $\mathrm{CHL}$ fibroblasts were incubated with tryptase in combination with EGF, bFGF, insulin, or thrombin. Threshold response concentrations of tryptase $(0.75 \mathrm{nM})$ in combination with either insulin, EGF, or bFGF elicited increasing synergistic responses (Fig. 3, $a-c$ ). Synergy was produced without an apparent shift in the concentration producing the half-maximal response for all three growth factors. In contrast, the $\left[{ }^{3} \mathrm{H}\right]-$ thymidine incorporation response to concomitant low concentration tryptase plus thrombin was additive rather than synergistic (Fig. $3 d$ ).

Tryptase is found in mast cell preparations noncovalently linked to, and stabilized by, heparin, a constituent of mast cell secretory granules (31). Heparin is known to modulate the effects of a number of mitogens, including members of the heparin-binding growth factor family, and may also have independent growth regulatory function $(32)$. The $\left[{ }^{3} \mathrm{H}\right]$ thymidine uptake response of CHL cells to $7.5 \mathrm{nM}$ tryptase was not altered by the addition of heparin when added to tryptase solutions in a weight ratio to tryptase of $2.5: 1$. Heparin alone at an equivalent concentration had no effect on thymidine incorporation (data not shown).

The possibility that proteinases exert their mitogenic effects through a mechanism that is dependent upon their catalytic activity continues to be an issue of great interest $(21,33)$. To determine whether preserved catalytic activity of tryptase is required for the mitogenic effect, we studied the effect of proteinase catalytic inhibition on DNA synthesis using leupeptin and DFP, two established tryptase inhibitors (22).

Incubation of CHL fibroblasts with tryptase in the presence of leupeptin resulted in a concentration-dependent inhibition of $\left[{ }^{3} \mathrm{H}\right]$ thymidine uptake (Fig. 4). Leupeptin concentrations above $300 \mu \mathrm{M}$ suppressed $\left[{ }^{3} \mathrm{H}\right]$ thymidine uptake by greater than $80 \%$. At the concentrations used, nonspecific effects of leupeptin were not observed, as demonstrated by the unaltered response to EGF in the presence of leupeptin (Fig. 4). Catalytic activity of tryptase after incubation with leupeptin ( $1 \mathrm{mM})$ was reduced to less than $0.5 \%$ of initial activity (data not shown), consistent with previous results (22). These results are compatible with the requirement for an intact catalytic site for tryptaseinduced stimulation of DNA synthesis. However, leupeptin is a 

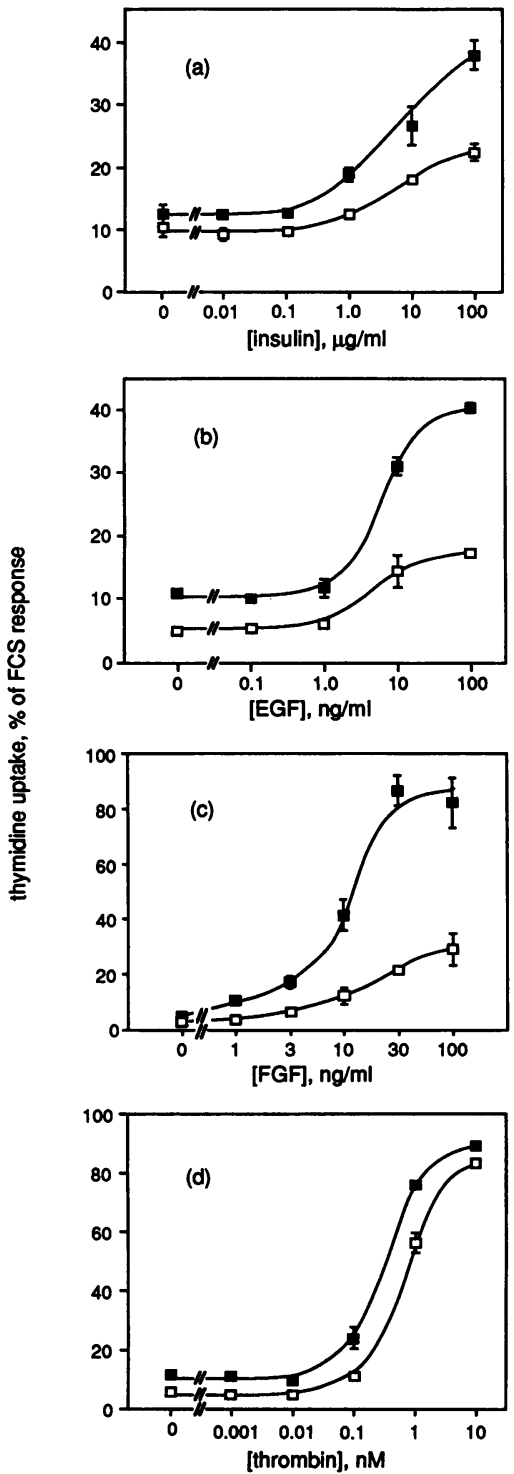

Figure 3. Reinitiation of DNA synthesis in CHL fibroblasts by tryptase in combination with insulin, EGF, bFGF, and thrombin. Results represent $24-\mathrm{h}\left[{ }^{3} \mathrm{H}\right]$ thymidine uptake responses for insulin $(a)$, $\operatorname{EGF}(b)$, bFGF (c), and thrombin $(d)$, alone (open symbols), and in combination with 0.75 nM purified tryptase (closed symbols). Radiolabel incorporation data are normalized to the response to $10 \%$ fetal bovine serum. Data are mean $\pm S D$ from $a$ representative experiments done in duplicate.

reversible inhibitor and could potentially affect other cellular proteins while in solution during the 24-h stimulation period.

As an alternative to leupeptin, we used DFP, an irreversible, covalent serine proteinase inhibitor, which can completely inhibit the catalytic activity of tryptase (22). When free in solution, this inhibitor is cytotoxic. Taking advantage of the instability of free DFP in aqueous solution, we incubated proteinases (both tryptase and thrombin) with DFP, and continued the incubations for $21 \mathrm{~h}$ at $4^{\circ} \mathrm{C}$ to allow for the hydrolysis of unincorporated DFP. Complete hydrolysis of DFP was confirmed by a lack of inhibition of proteinase amidolytic activity by the incubated DFP solutions; amidolytic activity of tryptase and thrombin in the absence of DFP did not diminish during incubation at $4^{\circ} \mathrm{C}$ (data not shown).

While the catalytic activity of tryptase was inhibited $98.7 \%$ by DFP, the reinitiation of DNA synthesis was reduced by only $60.9 \%$ (Table II). For thrombin, catalytic activity was inhibited greater than $99.2 \%$, while the mitogenic response of CHL cells to DFP-thrombin was inhibited by $85.2 \%$, in agreement with published data (34) (Table II). These data, together with the leupeptin inhibition results, suggest that expression of the full mitogenic activity of tryptase is dependent upon an uninhib-

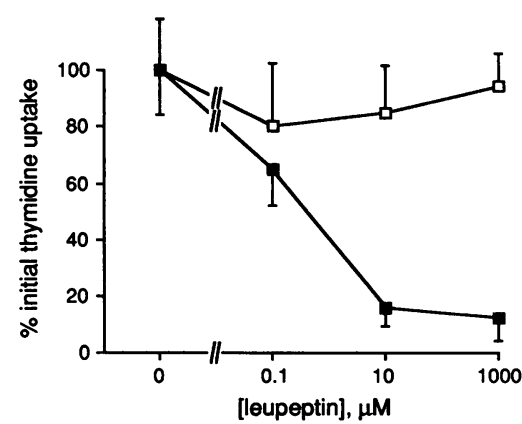

Figure 4. Effect of leupeptin on the CHL fibroblast thymidine uptake response to tryptase (7.5 nM; closed symbols $)$ and EGF (100 ng/ $\mathrm{ml}$; open symbols). Cells were incubated for $24 \mathrm{~h}$ in the presence or absence of the leupeptin concentrations shown, with tryptase or EGF. $\left[{ }^{3} \mathrm{H}\right]$ Thymidine incorporation results were normalized to results obtained in the absence of leupeptin. Data represent mean \pm SD from triplicate determinations.

ited catalytic site, although a catalytic site-independent component may exist. It remains to be proven that a proteolytic event is a necessary component of tryptase-induced mitogenesis.

Notwithstanding the finding that tryptase is a mitogen for Rat- 1 cells while thrombin is not, the similarities in the structure and catalytic activity of these two mitogens suggest the possibility of a shared mechanism of cell activation. To investigate this possibility, we compared the participation of both mitogens in known signal transduction pathways and responses.

Activation of the amiloride-sensitive $\mathrm{Na}^{+} / \mathrm{H}^{+}$antiporter is a virtually universal response of fibroblasts to mitogens, including thrombin, EGF, bFGF, and platelet-derived growth factor $(27,35,36)$. Measured in bicarbonate-free conditions, stimulation of $\mathrm{Na}^{+} / \mathrm{H}^{+}$exchange results in a transient intracellular alkalinization. Tryptase, like thrombin, increased intracellular pH transiently in CHL fibroblasts, an effect that was abolished by amiloride pretreatment of the cells (Fig. 5). Significant alkalinization was evident by $5 \mathrm{~min}$, was maximal $10 \mathrm{~min}$ after addition of tryptase, and decreased over the next $20 \mathrm{~min}$ (data not shown).

Important early cellular responses to growth factors include stimulation of phospholipase $\mathrm{C}$ (resulting in inositol phosphate formation), mobilization of cytosolic $\mathrm{Ca}^{++}$, and activation of GTP-binding proteins $(35,37,38)$. These responses are known to occur after fibroblast exposure to thrombin. Therefore, we compared the effects of tryptase and thrombin on formation of inositol phosphates, on changes in cytosolic $\mathrm{Ca}^{++}$concentration, and on reinitiation of DNA synthesis in the presence of pertussis toxin. The concentrations of tryptase and thrombin

Table II. Diisopropylfluorophosphate Inhibition of Tryptase and Thrombin: DNA Synthesis and Catalytic Activity Responses

\begin{tabular}{|c|c|c|}
\hline & Tryptase* & Thrombin ${ }^{*}$ \\
\hline Inhibition of DNA synthesis & $60.9 \pm 2.7 \%$ & $85.2 \pm 0.9 \%$ \\
\hline Inhibition of catalytic activity" & $98.7 \%$ & $99.2 \%$ \\
\hline
\end{tabular}

* Tryptase incubated at $3 \mu \mathrm{M}$; molar ratio of DFP to tryptase equaled 300:1. ${ }^{*}$ Thrombin incubated at $1 \mu \mathrm{M}$; molar ratio of DFP to thrombin equaled 100:1. ${ }^{5}$ Assayed by radiolabeled thymidine uptake (see Methods); compared with enzyme incubated $21 \mathrm{~h}$ at $4^{\circ} \mathrm{C}$, in the absence of DFP; mean \pm SE for triplicate determinations. " Assayed by cleavage of chromogenic substrate (see Methods); compared with enzyme incubated $21 \mathrm{~h}$ at $4^{\circ} \mathrm{C}$, in the absence of DFP. 


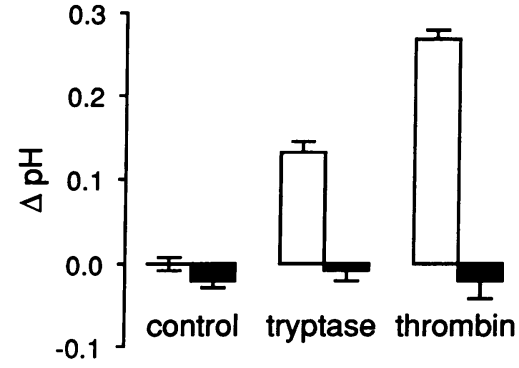

intracellular $\left[{ }^{14} \mathrm{C}\right]$ benzoic acid and calculation of changes in intracellular $\mathrm{pH}$ were performed as described in Methods. Data are mean \pm SD for triplicate determinations.

used in the following experiments were chosen because they result in similar $\left[{ }^{3} \mathrm{H}\right]$ thymidine uptake responses (see Figs. $1 a$ and $3 d$ ).

The total inositol phosphates generated after exposure of $\left[{ }^{3} \mathrm{H}\right]$ inositol-loaded CHL cells to proteinases was assessed by anion-exchange chromatography, as previously described (29). No increase in inositol phosphate formation was detected after tryptase stimulation, consistent with a lack of phospholipase $\mathrm{C}$ activation (Fig. $6 a$ ). In contrast, thrombin produced a marked increase in inositol phosphates, as previously reported (39).

An important cellular response to phospholipase $\mathrm{C}$ activation is the mobilization of intracellular $\mathrm{Ca}^{++}$, mediated through inositol-1,4,5-trisphosphate (37). Alternatively, cytosolic $\mathrm{Ca}^{++}$concentration can be elevated through influx of extracellular $\mathrm{Ca}^{++}(36,40)$. To determine whether tryptase alters $\mathrm{Ca}^{++}$homeostasis through a phospholipase $\mathrm{C}$-independent pathway, we examined the effect of tryptase on intracellular $\mathrm{Ca}^{++}$concentration, using the fluorescent $\mathrm{Ca}^{++}$-indicator fura2 (28). No increase in cytosolic $\mathrm{Ca}^{++}$concentration was observed after addition of $7.5 \mathrm{nM}$ tryptase to CHL cells (Fig. $6 b$ );
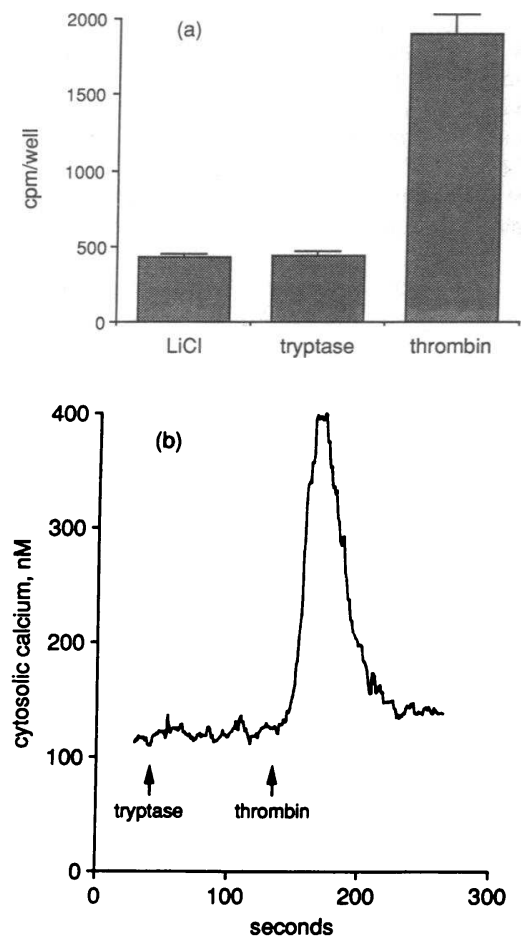

Figure 6. Effect of tryptase on inositol phosphate generation $(a)$ and cytoplasmic $\mathrm{Ca}^{++}$concentration $(b)$ in $\mathrm{CHL}$ cells. (a) Inositol phosphates generated after 10 min stimulation with tryptase $(7.5 \mathrm{nM})$ or thrombin $(1 \mathrm{nM})$ in the presence of $10 \mathrm{mM}$ $\mathrm{LiCl}$. Results represent mean cpm/well $( \pm \mathrm{SD})$ for three determinations. (b) Free cytosolic $\mathrm{Ca}^{++}$concentration measured in CHL cells using the fluorescent indicator fura-2. Tryptase (7.5 $\mathrm{nM})$ and thrombin (1 $\mathrm{nM})$ were added sequentially during continuous recording. The tracing shown is representative of three independent measurements. however, a prominent $\mathrm{Ca}^{++}$mobilization response was observed with $1 \mathrm{nM}$ thrombin, as previously reported (41). These results indicate that cytosolic $\mathrm{Ca}^{++}$is not used as a second messenger in signal transduction by tryptase.

Pertussis toxin-sensitive GTP-binding proteins have been shown to mediate the mitogenic signal of certain growth factors, including thrombin $(24,38)$. Tryptase-induced stimulation of DNA synthesis in CHL fibroblasts was unaffected by pertussis toxin over a concentration range of $1-10 \mathrm{ng} / \mathrm{ml}$, as was the response to EGF (Fig. 7), a mitogen thought to act through a pertussis toxin-insensitive pathway in fibroblasts (42). Pertussis toxin exposure produced significant inhibition of the thrombin-mediated mitogenic response (Fig. 7), in agreement with Chambard et al. (24).

\section{Discussion}

These data establish tryptase as a potent mitogen for fibroblasts in vitro. Tryptase induces the synthesis of DNA in fibroblasts with concomitant cell proliferation. Prompt activation of fibroblasts occurs upon tryptase exposure, as evidenced by $\mathrm{Na}^{+} / \mathrm{H}^{+}$ antiporter activation within $5 \mathrm{~min}$ of tryptase addition. Even at threshold concentrations, tryptase markedly potentiates the mitogenic response of fibroblasts to bFGF, EGF, and insulin. The marked reduction of tryptase-induced mitogenesis by proteinase inhibitors suggests that an intact, unoccupied catalytic site is required to exhibit the full response. In these respects, tryptase resembles thrombin, a serine proteinase with similar catalytic features $(22,43)$. However, although both enzymes stimulate DNA synthesis and cell proliferation in fibroblasts, and both activate the amiloride-sensitive $\mathrm{Na}^{+} / \mathrm{H}^{+}$antiporter, the two enzymes appear to activate different signaling pathways. The activation of fibroblasts by tryptase involves neither the breakdown of phosphatidylinositol phosphates nor an increase in cytosolic $\mathrm{Ca}^{++}$, both of which occur upon stimulation with thrombin. Furthermore, unlike thrombin, tryptase does not appear to activate cells through a pathway involving pertussis toxin-sensitive G-proteins. Although tryptase induces an eightfold increase in CHL cell number over a 6-day growth period, confluence is not achieved. The mechanism for this limit in proliferation is not known.

The specific signal transduction mechanisms responsible for the mitogenic effect of tryptase remain unresolved. However, two lines of evidence reinforce the specificity of tryptase-

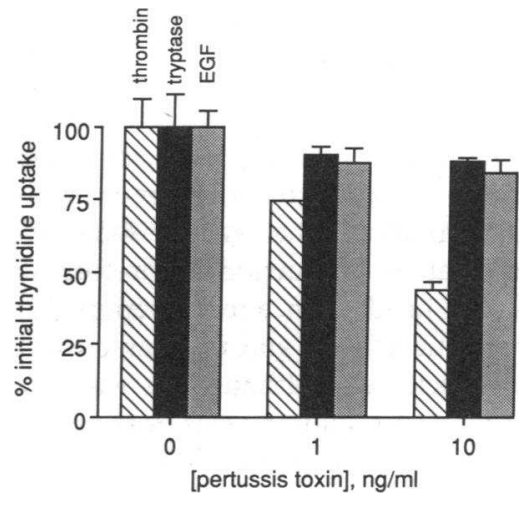

Figure 7. Pertussis toxin sensitivity of thymidine incorporation in response to thrombin ( 1 $\mathrm{nM}$; striped bars), tryptase (7.5 nM; black bars $)$, and EGF (100 $\mathrm{ng} / \mathrm{ml}$; gray bars) in CHL fibroblasts. Pertussis toxin was added to cells, at the concentrations indicated, $4 \mathrm{~h}$ before stimulation and was present throughout the 24-h incubation

with growth factors. $\left[{ }^{3} \mathrm{H}\right.$ ]Thymidine incorporation results were normalized to $100 \%$ for each agonist in absence of pertussis toxin and represent mean \pm SD for triplicate determinations. 
induced mitogenesis. First, two additional serine proteinases, trypsin and mast cell chymase, were also tested for their ability to induce DNA synthesis in fibroblasts. Trypsin has known mitogenic capacity in fibroblasts, particularly chick embryo fibroblasts, which appear exquisitely responsive to a number of proteinases $(21,44,45)$. Chymase, a chymotrypsin-like mast cell granule proteinase, has been implicated in extracellular matrix degradation and architectural alteration in fibroblasts after mast cell degranulation (46). In Rat-1 cells (Fig. $1 b$ ) and CHL fibroblasts (data not shown), neither trypsin nor chymase increased $\left[{ }^{3} \mathrm{H}\right]$ thymidine uptake, whereas tryptase produced striking responses at concentrations similar to, or lower than, those of trypsin and chymase. Second, a marked difference was observed in the $\left[{ }^{3} \mathrm{H}\right]$ thymidine incorporation responses of Rat1 cells to tryptase and thrombin. While both tryptase and thrombin stimulated DNA synthesis in CHL cells, only tryptase produced a response in Rat-1 cells.

The mechanisms underlying mitogenic activity of proteinases, such as thrombin, remain unclear despite considerable work in this field. The participation of proteolytic events in the activation of cells by proteinases has been proposed, though not conclusively established (21). As reported herein, inhibitors of catalytic activity (leupeptin and DFP) produce substantial reductions in the mitogenic response of fibroblasts to tryptase (Fig. 4, and Table II).

The observation that leupeptin and DFP diminish the mitogenic activity of tryptase is consistent with a number of hypotheses. One is that a specific proteolytic event is required for the initiation of signal transduction leading to DNA synthesis and cell proliferation. A second is that binding to the tryptase catalytic site is required, but that the binding protein (possibly a cell surface receptor) acts as a pseudosubstrate, not subject to cleavage. In the latter case, the proteinase would induce a critical conformational change in the transduction protein in the absence of a proteolytic event, thereby initiating cell activation. A third possibility is a binding interaction with a cell surface molecule involving a part of tryptase distinct from the active site.

Clearly, these hypotheses need not be mutually exclusive. Activation by tryptase may require both catalytic and noncatalytic events. It is interesting that the degree of mitogenic inhibition produced by leupeptin and DFP differs. Leupeptin, a tripeptide inhibitor, produces virtually complete mitogenic and catalytic inhibition, whereas DFP produces a lesser degree of mitogenic inhibition of $60 \%$, even though catalytic activity is inhibited almost completely. Given the size difference between these two inhibitors, the difference in magnitude of mitogenic inhibition could be explained by the presence of a binding epitope on tryptase that extends beyond the immediate substrate binding pocket. This binding region, although adjacent to the catalytic site, may not depend on a catalytic event for cell activation. Evidence exists for thrombin that a catalytic site-independent epitope may participate in production of a mitogenic signal in some target cells (47). In addition, a recent report (33) suggests dissociation of catalytic activity and mitogenic effect for thrombin in smooth muscle cells, although, as with the tryptase results presented here, the study reveals only partial inhibition of mitogenic activity by proteinase inhibitors. This would support a mixed catalytic site-dependent and -independent function of proteinases in mitogenic activation. The lack of any significant effect of trypsin or chymase on DNA synthesis in CHL and Rat-1 cells supports the conclusion that nonspe- cific cell surface proteolytic events are not sufficient to induce S-phase entry in these fibroblasts.

Our in vitro results provide strong support for the hypothesis that mast cell activation can lead to fibroblast proliferation in vivo, and for the possibility that tryptase plays an important role as mediator of this response. This hypothesis is also supported by existing knowledge concerning the activity, concentration, and tissue distribution of this proteinase. Tryptase is released from mast cells as a heparin-associated tetramer of catalytically active subunits, and is unusual among serine proteinases in being active in serum and highly resistant to inactivation by circulating inhibitors $(48,49)$. Furthermore, the concentrations of tryptase sufficient in our experiments to stimulate fibroblast growth directly or in synergy with other growth factors are predicted to be achieved readily in the microenvironment of the degranulating mast cell $(50,51)$. Finally, the wide distribution of tryptase-containing mast cells in humans suggests that tryptase may play a part in the development of fibrotic disorders affecting a variety of tissues, including lung, skin, and gut.

\section{Acknowledgments}

The authors thank Dr. K. Seuwen for assistance in inositol phosphate formation assays.

Dr. Ruoss is a Cystic Fibrosis Foundation Fellow. Dr. Hartmann is supported by the Deutsche Forschungsgemeinschaft. Dr. Caughey is a recipient of National Institutes of Health Clinical Investigator Award HL-07136 and of an RJR-Nabisco Research Scholar Award in Pulmonary.

\section{References}

1. Kawanami, O., V. J. Ferrans, J. D. Fulmer, and R. G. Crystal. 1979. Ultrastructure of pulmonary mast cells in patients with fibrotic lung disorders. $L a b$. Invest. 40:717-734.

2. Trabucchi, E., E. Radaelli, M. Marazzi, D. Foschi, M. Musazzi, A. M. Veronesi, and W. Montorsi. 1988. The role of mast cells in wound healing. Int. J. Tissue React. 10:367-372.

3. LeRoy, E. C., E. A. Smith, M. B. Kahaleh, M. Trojanowska, and R. M. Silver. 1989. A strategy for determining the pathogenesis of systemic sclerosis: is transforming growth factor $\beta$ the answer? Arthritis Rheum. 32:817-825.

4. Claman, H. N. 1989. On scleroderma: mast cells, endothelial cells and fibroblasts. JAMA (J. Am. Med. Assoc.) 262:1206-1209.

5. Watanabe, S., K. Watanabe, T. Ohishi, M. Aiba, and K. Kageyama. 1974. Mast cells in the rat alveolar septa undergoing fibrosis after ionizing radiation. Lab. Invest. 31:555-567.

6. Goto, T., D. Befus, R. Low, and J. Bienenstock. 1984. Mast cell heterogeneity and hyperplasia in bleomycin-induced pulmonary fibrosis in rats. Am. Rev. Respir. Dis. 130:797-802.

7. Wagner, M. M., R. E. Edwards, C. B. Moncrieff, and J. C. Wagner. 1984. Mast cells and inhalation of asbestos in rats. Thorax. 39:539-544.

8. Takiazawa, H., K. Ohta, K. Hirai, Y. Misaki, T. Horiuchi, N. Kobayashi, J. Shiga, and T. Miyamoto. 1989. Mast cells are important in the development of hypersensitivity pneumonitis. A study with mast-cell-deficient mice. J. Immunol. 143:1982-1988.

9. Beasley, R., W. R. Roche, J. A. Roberts, and S. T. Holgate. 1989. Cellular events in the bronchi in mild asthma and after bronchial provocation. Am. Rev. Respir. Dis. 139:806-817.

10. Claman, H. N., R. C. Giorno, and J. R. Seibold. 1990. Mast cell degranulation in scleroderma (SS). Clin. Res. 38:349 A.

11. Norrby, K., L. Enerback, and L. Franzen. 1976. Mast cell activation and tissue proliferation. Cell Tissue Res. 170:289-303.

12. Schwartz, L. B. 1987. Mediators of human mast cells and human mast cell subsets (published erratum appears in 1987. Ann. Allergy. 59:316). Ann. Allergy. 58:226-35.

13. Schwartz, L. B., R. A. Lewis, D. Seldin, and K. F. Austen. 1981. Acid hydrolases and tryptase from secretory granules of dispersed human lung mast cells. J. Immunol. 126:1290-1294.

14. Schechter, N. M., J. K. Choi, D. A. Slavin, D. T. Deresienski, S. Sayama, 
G. Dong, R. M. Lavker, D. Proud, and G. S. Lazarus. 1986. Identification of a chymotrypsin-like proteinase in human mast cells. J. Immunol. 137:962-970.

15. Caughey, G. H., S. C. Lazarus, N. F. Viro, W. M. Gold, and J. A. Nadel. 1988. Tryptase and chymase: comparison of extraction and release in two dog mastocytoma lines. Immunology. 63:339-344.

16. Jordana, M., A. D. Befus, M. T. Newhouse, J. Bienenstock, and J. Gauldie. 1988. Effects of histamine on proliferation of normal adult lung fibroblasts. Thorax. 43:552-558.

17. Franzen, L., and K. Norrby. 1980. Local mitogenic effect of tissue mast cell secretion. Cell Tissue Kinet. 13:635-642.

18. Marks, R. M., W. R. Roche, M. Czerniecki, R. Penny, and D. S. Nelson. 1986. Mast cell granules cause proliferation of human microvascular endothelial cells. Lab. Invest. 55:289-294.

19. Chen, L. B., and J. M. Buchanan. 1975. Mitogenic activity of blood components. I. Thrombin and prothrombin. Proc. Natl. Acad. Sci. USA. 72:131135.

20. Carney, D. H., and D. D. Cunningham. 1978. Cell surface action of thrombin is sufficient to initiate division of chick cells. Cell. 14:811-823.

21. Scher, W. 1987. Biology of disease: the role of extracellular proteases in cell proliferation and differentiation. Lab. Invest. 57:607-633.

22. Caughey, G. H., N. F. Viro, J. Ramachandran, S. C. Lazarus, D. B. Borson, and J. A. Nadel. 1987. Dog mastocytoma tryptase: affinity purification, characterization and amino-terminal sequence. Arch. Biochem. Biophys. 258:555-563.

23. Caughey, G. H., N. F. Viro, S. C. Lazarus, and J. A. Nadel. 1988. Purification and characterization of dog mastocytoma chymase: identification of an octapeptide conserved in chymotryptic leukocyte proteinases. Biochim. Biophys Acta. 952:142-149.

24. Chambard, J. C., S. Paris, G. L'Allemain, and J. Pouyssegur. 1987. Two growth factor signalling pathways in fibroblasts distinguished by pertussis toxin. Nature (Lond.). 326:800-803.

25. Witting, J. I., C. Pouliott, J. L. Catalfamo, J. Fareed, and J. W. Fenton II. 1988. Thrombin inhibition with dipeptidyl argininals. Thromb. Res. 50:461-468.

26. Hartmann, T., K. Seuwen, M. F. Roussel, C. J. Sherr, and J. Pouyssegur. 1990. Functional expression of the human receptor for colony stimulating factor 1 (CSF-1) in hamster fibroblasts: CSF-1 stimulates $\mathrm{Na}+/ \mathrm{H}+$ exchange and DNA synthesis in the absence of phospholipid breakdown. Growth Factors. 2:289-300.

27. L'Allemain, G., S. Paris, and J. Pouyssegur. 1984. Growth factor action and intracellular $\mathrm{pH}$ regulation in fibroblasts. Evidence for a major role of the $\mathrm{Na}^{+} / \mathrm{H}^{+}$antiport. J. Biol. Chem. 5809-5815.

28. Grynkiewicz, G., M. Poenie, and R. Y. Tsien. 1985. A new generation of $\mathrm{Ca}^{++}$indicators with greatly improved fluorescence properties. J. Biol. Chem. 260:3440-3450.

29. Seuwen, K., I. Magnaldo, and J. Pouyssegur. 1988. Serotonin stimulates DNA synthesis in fibroblasts acting through 5-HT1B receptors coupled to a Giprotein. Nature (Lond.). 335:254-256.

30. Hallcher, L. M., and W. R. Sherman. 1980. The effects of lithium and other agents on the activity of myo-inositol-1-phosphatase from bovine brain. $J$. Biol. Chem. 255:10896-10901.

31. Schwartz, L. B., and T. R. Bradford. 1986. Regulation of tryptase from human lung mast cells by heparin. Stabilization of the active tetramer. J. Biol. Chem. 261:7372-7379.

32. Ruoslahti, E. 1989. Proteoglycans in cell regulation. J. Biol. Chem. 264:13369-13372.
33. Bar-Shavit, R., M. Benezra, A. Eldorf, J. W. Fenton II, G. D. Wilner, and I. Vlodavsky. 1990. Thrombin immobilized to extracellular matrix is a potent mitogen for vascular smooth muscle cells: nonenzymatic mode of action. Cell Regulation. 1:453-463.

34. Glenn, K. C., D. H. Carney, J. W. I. Fenton, and D. D. Cunningham. 1980. Thrombin active site regions required for fibroblast receptor binding and initiation of cell division. J. Biol. Chem. 6609-6616.

35. Rozengurt, E. 1986. Early signals in the mitogenic response. Science (Wash. DC). 234:161-166.

36. Moolenaar, W. H. 1986. Effects of growth factors on intracellular pH regulation. Annu. Rev. Physiol. 48:363-376.

37. Berridge, M. J. 1984. Inositol trisphosphate and diacylglycerol as second messengers. Biochem. J. 220:345-360.

38. Murayama, T., and M. Ui. 1987. Possible involvement of a GTP-binding protein, the substrate of islet-activating protein, in receptor-mediated signaling responsible for cell proliferation. J. Biol. Chem. 262:12463-12467.

39. Raben, D. M., and D. D. Cunningham. 1985. Effects of EGF and thrombin on inositol-containing phospholipids of cultured fibroblasts: stimulation of phosphatidylinositol synthesis by thrombin but not EGF. J. Cell. Physiol. 125:582-590.

40. Pandiella, A., A. Malgaroli, J. Meldolesi, and L. M. Vicentini. 1987. EGF raises cytoslic $\mathrm{Ca}^{++}$in $\mathrm{A} 431$ and Swiss $3 \mathrm{~T} 3$ cells by a dual mechanism. Exp. Cell Res. 170:175-185.

41. Magnaldo, I., G. L'Allemain, J. C. Chambard, M. Moenner, D. Barritault, and J. Pouyssegur. 1986. The mitogenic signalling pathway of fibroblast growth factor is not mediated through polyphosphoinositide hydrolysis and protein kinase $C$ activation in hamster fibroblasts. J. Biol. Chem. 261:16916-16922.

42. L'Allemain, G., K. Seuwen, T. Velu, and J. Pouyssegur. 1989. Signal transduction in hamster fibroblasts overexpressing the human EGF receptor. Growth Factors. 1:311-321.

43. Hemker, H. C. 1983. Substrates. In Handbook of Synthetic Substrates for the Coagulation and Fibrinolytic System. Matinus Nijhoff, Boston. 53-93.

44. Burger, M. M. 1970. Proteolytic enzymes initiating cell division and escape from contact inhibition of growth. Nature (Lond.). 227:170-171.

45. Zetter, B. R., L. B. Chen, and J. M. Buchanan. 1976. Effects of protease treatment on growth, morphology, adhesion, and cell surface proteins of secondary chick embryo fibroblasts. Cell. 7:407-412.

46. Ginsburg, H., M. Amira, J. Padawer, and S. Davidson. 1989. Structural alterations in fibroblast monolayers caused by mast cell degranulation. J. Periodontal Res. 24:41-4.

47. Bar-Shavit, R., A. J. Kahn, K. G. Mann, and G. D. Wilner. 1986. Identification of a thrombin sequence with growth factor activity on macrophages. Proc. Natl. Acad. Sci. USA. 83:976-980.

48. Smith, T. J., M. W. Hougland, and D. A. Johnson. 1984. Human lung tryptase. Purification and characterization. J. Biol. Chem. 259:11046-11051.

49. Alter, S. C., J. A. Kramps, A. Janoff, and L. B. Schwartz. 1990. Interactions of human mast cell tryptase with biological protease inhibitors. Arch. Biochem. Biophys. 276:26-31.

50. Schwartz, L. B., A.-M. A. Irani, K. Roller, M. C. Castells, and N. M. Schechter. 1987. Quantitation of histamine, tryptase, and chymase in dispersed human T and TC mast cells. J. Immunol. 138:2611-2615.

51. Sekizawa, K., G. H. Caughey, S. C. Lazarus, W. M. Gold, and J. A. Nadel. 1989. Mast cell tryptase causes airway smooth muscle hyperresponsiveness in dogs. J. Clin. Invest. 83:175-179. 